\title{
Alternative Spaces \& Artist Agency in the Art Market
}

\author{
Olga Kanzaki Sooudi
}

Department of Anthropology, University of Amsterdam, 1018 WV Amsterdam, The Netherlands; o.k.sooudi@uva.nl

Received: 21 August 2020; Accepted: 26 October 2020; Published: 10 November 2020

\begin{abstract}
This article explores what alternative, or artist-led, spaces are in Mumbai today and their role within the city's artworld. Drawing on ethnographic fieldwork in two alternative spaces, it argues that these are artist attempts to exercise agency in their work for an uncertain market context. In other words, these spaces are a strategy for artists to exercise control over their work in an uncertain art market, and a means to counterbalance their dependence on galleries in their careers. Furthermore, artists do so through collectivist practices. These spaces, I argue, challenge models of artistic and neoliberal work that privilege autonomy, independence, and isolation, as if artists were self-contained silos of productive creative activity and will. Artists instead, in these spaces, insist on the importance of social bonds and connection as a challenge to the instrumentalization and divisive nature of market-led demands on art practice and the model of the solo genius artist-producer. At the same time, their collective activities are oriented towards supporting artists' individual future market success, suggesting that artist-led spaces are not separate from the art market, and should be considered within the same analytical frame.
\end{abstract}

Keywords: alternative spaces; artist-led spaces; artists; artistic labor; agency; art markets; market alternatives; emerging art; collectives; India

\section{Introduction}

Sundays were bustling at Cona, an artist-led space in Borivali, a northern Mumbai suburb. Whereas during the rest of the week occupants were limited to the founders-two artists who lived there-an artist-in-residence, and a small number of other artists who came in and out to help or for meetings, on many Sundays, Cona opened its doors for a series of artist-centered events lasting well into the night. The gathering started small-I arrived mid-day at the low-lying, concrete bungalow, where a cat and her kittens lapped at a pan of milk set out by one of the artists. The afternoon began with a hot lunch on stainless steel plates, laid out on newspapers spread on the floor. The founders, Shreyas and Hemali, sat alongside a few other artists in their 30s, and a handful of younger art college students, chatting. It was informal, friendly, and cozy; outside in the sun, a couple of dogs wandered about. After lunch, and more chatting and chai on the terrace, several new students arrived, including a group of young men enrolled at an art college in Vasai, a suburb even further north of the city. This second event was pedagogical in aim, a feedback session for three of the Vasai students. They spread their portfolios out on the marble floor: paintings next to charcoal sketches and drawings in blue ballpoint. Everyone circled the works, padding around barefoot and studying them for a few minutes, before Hemali and Shreyas began to comment on the works, asking their authors about their aesthetic choices as they went on.

Activity intensified after sunset. Following the feedback session more artists arrived-older ones-as well as a number of curators I recognized from other art spaces in Mumbai. More socializing over chai and cigarettes on the terrace, now bathed in twilight, came before a presentation from a visiting curator from Kadist in Paris, and another local curator and artist, everyone sitting cross-legged 
on the floor inside, images projected onto the wall. Next, Shreyas and another artist led a conversation about the role of pedagogy in artists' practice; how to balance making art with other forms of work; and the possibility of making adequate income as an artist. The evening ended once again on the spacious terrace, people chatting and chain-smoking. The students transformed into servers and assistants, bringing out large trays of snacks, more hot tea, and some drinks. One student walked around with a small box, gently asking everyone present for contributions to the costs of food and drink, noting down names and amounts carefully on a slip of paper.

Cona is one of two alternative art spaces in Mumbai explored in this article. As this vignette shows, several kinds of artist-led and -oriented activities unfold in these spaces. Over the course of one day, artists meet to socialize and connect over food and drink; discuss shared challenges in their work and engage in art critical debate; are exposed to and learn from international and other curators and experts about issues expanding their professional knowledge; and young artists receive feedback on their portfolios and career advice from more senior artists.

This article explores alternative, or artist-led spaces in Mumbai today. The question I explore is why artists created and participate in such spaces in the wake of the art market's globalization, boom, and bust over the last decade. I argue that they constitute artists' strategies to exercise and create agency and control over their work in an uncertain market context. My conclusions are that these spaces are artist responses to the commercialization of art, and specifically a way for them to have some agency over their careers and to help them navigate a highly marketized art world in India centered around the gallery system. My findings show that artists work collectively to help one another in their quotidian livelihoods, as well as in creating access to an elite art world. For younger, less advantaged, and privileged artists, these spaces provide collective support, in the form of material, artistic, and professional advice. For more established artists, these spaces provide an opportunity to meaningfully contribute to other artists, engage in discussions and social connection with other artists about their work conditions, artistic ideas, and do so without the intervening presence of the gallery or dealer, or curator. For all participants, these spaces enable professional identity production (Plattner 1996). In other words, these independent spaces enable artists to both possibly enter (younger ones) and temporarily and partially exit (established ones) the art market. Further, my findings challenge contemporary and classic characterizations of the artist as lone, hyper-individualistic, self-focused figure and ideal flexible neoliberal worker, which artists themselves internalize. By contrast, I show that, in Mumbai, artists seek one another out and want agency over their work, and they achieve this through collective means. Artists challenge neoliberal models: they strive for a practice not driven by the solo creator's "self-definition and self-validation," but instead is an ongoing undoing of the ideal of the artistic self's priority and sufficiency (Brouillette 2014, p. 17). As "parallel systems" to the art market, these Mumbai spaces do not so much challenge the latter, but seek to accommodate it while simultaneously fostering artist agency within the market. They do so via collective artist-led responses that draw boundaries around the market as a separate but interrelated sphere.

\section{Outline of Article \& Methods}

The first section of the article reviews conceptualizations of artistic labor and the artist as a modern figure with a distinct relationship to work, as well as how these have been picked up by scholars writing about the creative economy. Out of these diverse strains emerges a notion of the artist as the ideal, or vanguard, flexible neoliberal worker-highly individualist, working autonomously, privileging freedom, and in brutal competition with other brand-artists. Next, I contrast these perspectives on artistic labor and identity with different possibilities for these offered by independent, artist-led spaces and their ideological underpinnings. In particular, I consider the notion of the "alternative art space" as both a concept as well as a type of actual space in which artist-led activities unfold. While the term alternative is little used today to describe these spaces, its articulation through the history of such spaces offers a means of conceptualizing the relationship between artists and their work that gives artists more agency and power than the model of artist as ideal neoliberal worker does. 
The following sections present data from my fieldwork in two independent, artist-led spaces in Mumbai, Cona and Clark House Initiative, hereafter "CHI" (both established in 2010), carried out over five research periods between 2013 and 2018. Based on participant observation, interviews, and informal conversations with a wide range of artists and some curators engaged in varying degrees of participation in these two spaces, these findings show how artists participate in and co-produce these spaces as a form of critique of artworld accessibility and participation; to achieve a degree of artistic and material autonomy in relation to the mainstream gallery system; and to foster social bonds and identity production as artists. The artists discussed here are all visual artists who received formal art training. They all identified with conventional parameters of contemporary art, and a modern, European-derived notion of artist, and located their art practice within genealogies of both modern Indian and Euro-American art. Thus they represent only one, albeit highly prominent segment of art in India today.

\section{Artists \& Artistic Labor}

Artists are but one type of actor within collective processes of art-making, which includes mediators like gallerists/dealers, curators, art critics, among others, as well as those individuals who manufacture art objects under the direction of artists. However, artists, as those designated the authors of artworks, are seen as special due to having talents and gifts only shared by a few, and as the creative source generating an artwork (Becker 1982). This romantic myth about artists suggests that as special individuals, artists "cannot be subjected to the constraints imposed on other members of society;" in return for breaking the rules, artists are supposed to provide society with their works' "unique character and invaluable quality" (ibid., pp. 14-15). In the sociological and anthropological literature art is recognized as a fundamentally cooperative and collective process, involving a wide range of individuals and highly specialized division of labor in order to produce the art system through which a work circulates. Yet these models still maintain that artists are an exceptional type, exempt from and above other, more ordinary workers. In modern, hegemonic definitions of art, as undergird the global art market, artists also occupy a special role as the solo authors and creative source of artworks, whether or not they materially make the artworks themselves (c.f., Becker 1982; Bourdieu 1985, 1993).

The humanities literature provides a useful angle from which to denaturalize and critique this distinct characterization of the artist figure, which bears many resemblances with the classic trope of the artist as originally envisioned in the work of Charles Baudelaire. The notion of the artist as extremely independent, individualistic, and self-focused worker, in a separate, special category from other ordinary work originates in the 19th century. The artist is exemplified by the figure of the flâneur, who walked the streets of Paris, disdaining ordinary work, and through his powers of observation, engaged in creative and artistic production. These images portray the artist as a kind of "resisting, elite-aesthete artist-author," and propose that the artist is an isolated figure who works in isolated ways, and is focused on their own creative production, with little interest in or time to cooperate with others (Brouillette 2014, p. 37). Creative expression is seen as an expression of unique, individual genius, an "essence of experimentation emanating from an internal, natural, or biological source," and finds evidence for this in artists' purported resistance to routine, management, and commodification-they are wild, free figures (ibid., p. 35).

Although this figuration of the artist is a trope in the humanities literature, rather than a social fact, it remains useful to bring it into discussion here for two reasons. Firstly, artists do espouse this characterization in their own professional identities, and use it to evaluate their own work. For instance, they may make clear distinctions between "real" or "serious" artists who are devoted to their practice which has lofty, transcendent goals, and those artists who are just hobbyists or do it only for the money and are therefore not true artists, and this in turn reflects in the choices artists may make about how to work and share their artwork (Plattner 1996). Secondly, the model of artist as special, elevated, solo talent is an organizing category in the art market. Artists make individual names for themselves, and galleries by far represent individual artists; auction rankings do so by individual 
artist names. Prices for artist work are determined by galleries per artist, and in relation to other artists, whereas price distinctions within an artist's oeuvre are eschewed (Velthuis 2005). In building their careers, artists adopt commercial strategies that seek to exaggerate, highlight, and promote their individual, unique talent and brand (Win 2014). As I further explore below, these realities suggest that for artists today, collective practices and artistic identities are in tension with hegemonic ideals and norms that do not reward them. This modern, Western model of the artist as individual, special creative genius applies to the Indian context as well, and is espoused by those I spoke with in Mumbai.

Apart from a particular professional identity, artistic work is marked by unpredictability and uncertainty. Menger describes this unpredictability as twofold. First, there is the unpredictability of income and work opportunities, due to constant oversupply and the high differentiation of artistic products. Artists have uneven track records often in terms of income; they go in and out of periods of generating income by selling art (Menger 1999, 2001); in order to support themselves artists often work in other jobs such as teaching that mitigate against uncertainty (Plattner 1996). Second, unpredictability also has to do with the nature of the creative process itself. Menger writes that an artist does not know how their work or ideas will develop, or the skill that this will require. Artistic work, in terms of the creative process, is nonroutine and unpredictable, thus providing a "high learning potential" (252). All of these, he writes, are attractive to those who become artists. In Mumbai, the artists I encountered also experienced these two kinds of unpredictability: one, regarding income and work, that produced anxiety and worry among those who did not have access to regular sources of income, such as most of the young artists, and two, in terms of the nonroutine, non-linear nature of creative work which they celebrated and enjoyed. Thus, artistic labor markets expand along a path of highly unbalanced growth-combining contingency with entrepreneurialism (Menger 2001, p. 252).

The symbolically privileged place of the artist in an art system is reinforced as artists today draw increasingly from business models to ensure career success by making a name for themselves, and mitigate financial precarity. Artists attend business and marketing seminars to learn how to promote their work, and adopt entrepreneurial approaches, such as crowdfunding to fund an artwork (Win 2014), and engaging in self-branding practices (Taylor 2018). Gerber and Childress (2017) found that artists today reflect a more neoliberal conceptualization of themselves than in the 1960s and 1970s, as they adopt a service-based view of their work, encompassing labor time, services, skills, as well as products in evaluating their labor, in contrast to earlier object-based views of artistic work.

Brouillette argues these images have been taken up by creative economy discourses and initiatives to harness creative labor for capital, as artists are constructed as an ideal of nonalienated labor, whose creative autonomy is integrated into and managed through the workplace. This has been made possible by shifts in capitalism since the 1970s, which has expanded a network-based form of organization based on worker autonomy and initiative. The latter are usually framed as "freedom" for workers, that comes at the cost, however, of material and psychological security. Artists in particular are upheld as the ideal model for such freedom in work (Boltanski and Chiapello 2005). Yet, the limitless "mental reserves" of the worker-artists are exploited by industry: the artist's supposed independence and resistance to ordinary work and routine are incorporated as a productive capacity serving capital's goals, as they justify material insecurity, precarious work, irregular income, and lack of infrastructural support (Brouillette 2014; Florida 2002). Artists are figures mainstreamed as valorized mental laborers (ibid., p. 49).

These different threads of the literature from the social sciences and humanities show the complex and apparently paradoxical relationship between creative or artistic labor and capital, embodied in the artist and his/her work. On the one hand, artists are conceived as privileged, solo, creative, authorial figures, with a high degree of freedom in their work, which is also deemed as special and transcendent compared with other kinds of jobs. On the other hand, artists seem to be on the frontline of flexible, neoliberal work arrangements. They must continuously negotiate contingency and fluctuating opportunities and income in a hierarchical art system, and because of the nature of artistic work as internal process and artists, they do so largely alone, through strategies like self-branding. Further, 
the image of hyper-individualistic, valorized mental laborer makes artists amenable to exploitation, and is extended to exploit other types of workers as well. Finally, collective practices and behavior seem fraught for artists in an art market that is organized around and valorizes the individual artist-author.

\section{Alternative Space as Concept}

Alternative or independent spaces are usually seen as beyond the purview of the art market, because they are defined and self-identify as non-commercial spaces-CHI calls itself an "artists' union" or "collective," and Cona is a non-profit organization that also call itself a collective. Studies of art markets generally focus solely on sites of commercial transactions-the private gallery, art fairs, and auctions-whereas non-profit venues like alternative or independent art spaces, or biennials, for instance, are treated separately. This literature also emphasizes the roles of commercial actors, like dealers, auctions, and collectors as buyers, whereas artists are understood to have little agency in market processes, such as the creation of value and markets for their work. Artists rely instead on intermediaries, tastemakers, and consumers for these, yet are often highly aware of market processes, and try to respond to consumers and markets via aesthetic choices (Myers 2002; Chibnik et al. 2004, p. 5; Plattner 1996; Sooudi 2018) and defining the valuation of their labor time and works (Gerber 2017). This article builds on the interdisciplinary art markets literature by extending an examination of how artists exercise agency over their artistic practice and careers in relation to the art market, and how artists do this collectively, through structures conventionally considered beyond the art market-the alternative space.

The role of art collectives and independent artist-led spaces has been highlighted by art scholars in relation to the turn to collectivist or collaborative practices in contemporary art over the last decade. These focus on how artists engage in network-based, horizontal forms of art production and dissemination to challenge the hegemony of traditional institutions like the museum or gallery, while also expanding art's audiences, and engaging in activist art in relation to local communities and current political issues. The solo figure of the artist-author is challenged via forms of participatory or relational art that entail collective authorship of artworks (Enwezor 2005; Kester 2011; Papastergiadis 2011). In Global South contexts, artists have increasingly turned to collaborative and alternative practices because of their discomfort with the growing integration between the critical and gatekeeping institutions and actors of the art world, and sites of market transactions like galleries and art fairs (Kelley and Grant 2017). Here, I contribute to this literature on collective practices in contemporary art, and how artists negotiate the fraught relationship between artistic creation and artistic validation in a market context by extending my attention beyond what artists produce to the consequence of collective practices, and what they are, in relation to artistic labor itself.

Scholars have examined the emergence of alternative art spaces in places like New York City in the late 1960s and 1970s. Their creation was led by avant-garde artists seeking alternatives to the mainstream art system and its commercialized modes of art circulation and display, as embodied in the gallery (Terroni 2011). They were the spontaneous artist initiatives, in contrast to the institutional gallery (ibid.). Coined by the artist Brian O'Doherty in the early 1970s, the term 'alternative art spaces' generally refers to different means by which artists exhibit their work outside of the formal museum or commercial gallery, and included using studios for exhibitions, and the occupation of abandoned industrial buildings by artists, as well as artist cooperatives (ibid., p. 3). Julie Ault (2002) gives a more detailed definition for such "alternative structures," paying attention to the missions and origins of these organizations: they claim to fill a particular gap; to "counter the status quo of mercantile circuits"; and to address artists' needs not addressed anywhere else. Further, they claim to define themselves as any one or combination of anti-establishment, anti-institutional, experimental, artist-initiated, artist-run, or artist-centered (14). They are thus both a material and a theoretical space, as well as an experience. Both CHI and Cona adopted all these aspects in their practices.

These early alternative spaces enjoyed a heyday in the 1970s, and gradually faded out, as did the label, since the late 1990s, as it became increasingly impossible for artists to imagine any real outside 
to the commercial art system. The term "alternative" is contentious, like the phrases "marginal," or "oppositional," in relation to art spaces, because they potentially reinscribe and undergird a hierarchical view of the art field, in which hegemonic centers are reinforced by the presence of marginal alternatives (Ault 2002, p. 10). The leaders of the two Mumbai-based spaces I discuss here both told me that they would not call their spaces an alternative space, eschewing this in favor of terms like "collective" or "community," or, in the case of Cona, wishing not to have a label at all.

Yet the term is still useful because it highlights the historical and critical relations between existing institutions and practices in a given context, on the one hand, and structures and practices classified as alternative, on the other (ibid.). Thus, I use "alternative space" as a conceptual inspiration in this article, because this term captures some of the conceptual, social, and political stakes in these spaces, that are key to their meanings and operation, in the following ways. One, the spaces I examine here are about process, not finished outcome or static institutions. Not only are they ephemeral in terms of what they do and practice, they are also ephemeral as phenomena, a kind of anti-institution. For this reason, it does not make sense to talk about their success or failure in terms of their duration or in these terms at all. Compared to their predecessors, alternative or artist-led spaces today are ever-more transient and temporary, as people come together for specific projects, facilitated by communication technologies (Enwezor 2005). Secondly, CHI and Cona are alternatives to the mainstream art system. In Mumbai, these two are alternatives to the gallery system primarily located in South Mumbai, the elite center of the art world, and present themselves as such. Thirdly, these spaces are critical of the mainstream. In Mumbai, these consist of what artists perceive as the elitism, English-centrism, and classism of the art world.

Four, alternative spaces are both material and theoretical spaces. They are actual spaces as well as ideas of spaces and the possibilities for what can happen within them. The material space is often a building, or part of a building, in a certain location, but it can also be a magazine, or an online area. Their theoretical aspect is important in the sense that they are about the idea of having an alternative (space) in relation to the mainstream. They exist as a manifestation of an idea of critique and the need for experimental, avant garde, other spaces. This is their spirit.

Five, related to the above, alternative spaces often emerge as critiques of the economics of the art system, and reject market-driven concerns (Rachleff 2012). They have no money, except public money, which has strings attached to it influencing the conditions of running a space and its workings. This means such spaces tend not to last long, or are constantly evolving. I nuance this definition in my exploration of these two spaces in Mumbai, as artists did not fully reject or oppose the market, but rather condemned art's over-commercialization and artists' dependence on the commercial gallery, cultivating alternatives to it while collectively finding ways to navigate the market as an essential aspect of their career trajectories.

\section{The Art Market Context in India}

The markets for contemporary art that have developed-and continue to emerge-in many parts of the world, and especially in the Global South, since the late 1990s, index new practices, infrastructure, norms, and professional roles for how contemporary art is produced, circulated, displayed, and exchanged (c.f., Velthuis and Curioni 2015). Changes in the scale, form, and visibility of the art market in these new contexts have often been dramatic and rapid, appearing to mark a radical break with the past. This has especially been the case in India, where the global rise in contemporary (and modern) art prices resulted in a market "boom" that culminated in 2005-2008. The rise in art prices in India was particularly steep as compared with other emerging art markets such as Brazil, Russia, and China. Although the boom collapsed soon after, these market-led changes led to dramatic, long-term shifts in the Indian art scene, and the emergence of new forms of art world infrastructure. These shifts might be summarized in terms of the greater embedding of the market as a central locus of art world activities. India's art market began to grow post-liberalization of the national economy beginning in 1990, paralleling the growth of many new media and culture industries, such 
as advertising (Mazzarella 2003), television, as well as luxury markets (Vasudev 2012). To illustrate, both Mumbai and Delhi, which are the main art centers in India and South Asia, had only a tiny handful of galleries before the 2000s. There were only three commercial galleries in Mumbai before the late 1990s. Almost all of the prominent galleries in Mumbai were established in the 2000s. Foreign auction houses like Christie's and Sotheby's arrived in India in the mid-1990s, and the India Art Fair, the first international art fair, started in 2008. These changes occurred very rapidly: the turnover in Indian art grew from approximately US\$ five million in 2003, to US\$ 350-400 million in 2011 (c.f., Sharma 2012). In terms of museums, India has very few when it comes to modern or contemporary art, in part because recent art had very little role to play in the story of national development and arrival related in Nehruvian era art museums, established in the 1960s (Singh 2010). Private patronage has an important role, and a number of biennales have started up in recent years across South Asia, in India, namely the Kochi Muziris Biennale in 2012. In India, the private sector (specifically commercial galleries) is openly acknowledged as playing a major role in establishing who is and is not included in known regional contemporary art.

It was in the wake of the so-called boom that the two alternative spaces discussed here emerged, among others. Both $\mathrm{CHI}$ and Cona emphasized in interviews that their organizations were established in response to what their founders viewed as the over-commercialization of contemporary art in India, which had risen to new heights in the 2000s. During that time, art prices rose and then fell dramatically, and after the recession began in 2009, many, artists, dealers, collectors, and curators alike lamented that Indian art had become the object of financial speculation that ultimately failed, to the detriment of art, and contemporary art in particular, artists overproduced under pressure to meet market demand, resulting in mediocre work whose value did not endure (c.f., Sooudi 2018; Komarova 2017). India has a history of artist-led initiatives around the country, some which eventually institutionalized, like Khoj in Delhi, ${ }^{1}$ and others which eventually collapsed, like Open Circle in Mumbai in the 1990s, which focused on issues of urban inequality (c.f., Zarobell 2017). Such spaces are thus by no means anomalies in India, and there are others in Mumbai today. Like the global history of artist-led initiatives suggests, such spaces often either become more formalized and regulated, or they continue to change and in many cases dissolve once they meet their goals, or circumstances change, as I will return to later in this article. CHI and Cona are worthy of study in relation to artistic labor and collective practice specifically because they were historically located responses to transformations in the art market and its new centrality in processes of art production and circulation, and the consequences of these for artists.

Finally, not all young artists choose to participate in alternative art spaces in India. Many artists I met in Mumbai did not participate in any such space, and those who did found out about them by word of mouth, personal introductions, or via meeting one of the founders. It is difficult to generalize about career paths of all artists, but in my fieldwork, artists and galleries agreed that in an ideal trajectory, a young artist would have residencies domestically or abroad after graduation, that would enable them to further develop their practice, and eventually find gallery representation. In terms of livelihood, there was considerable variation, as some artists' paths were limited by financial means, and they moved on to other work to support themselves, whereas a few had families sufficiently wealthy to provide for their living costs, enabling the artists to take a longer period in trying to establish themselves. I did not mean any of the latter category in the alternative spaces.

\section{Cultivating Accessibility and Anti-Elitism in the Art World}

$\mathrm{CHI}$ brought together art historical, curatorial, political, and economic concerns in their organization and practices. "Clark House is not a social organization. We are not a help group,

1 For instance, Khoj features some of India's most well-known and market successful artists on its board, like Bharti Kher, and has received funding from many sources, also international, which is very different from the newer, still less-institutionalized initiatives like Cona (c.f., Yee 2012). 
we are not doing charity. We are an artists' union, a movement of sorts. We are trying to figure out the idea of contemporaneity" (Zasha Colah). They explored the question of contemporaneity in both local and national terms, by including the work of younger, less privileged artists, often from outside of the art centers of Mumbai and Delhi, and supporting art exploring issues of social, economic, and political inequality; and globally, by taking issue with hegemonic global art historical narratives, where countries of the global south like India have marginal place. In books, Zasha said, "There's a few pages on Persian art, and so on. India is just an add-on". CHI wanted to challenge these narratives, and sought greater inclusion for art from India on the global stage, while simultaneously seeking greater social inclusion within the Indian art world. ${ }^{2}$ Their interests were wide-ranging, from questions of how to honor Mumbai's cosmopolitan, mercantile history in what they saw as an increasingly conservative, Hindu nationalist political context, to the historical imposition of Hindi as hegemonic language in an inherently linguistically diverse country and region, to the mismatch between global narratives of India as economic superpower and the reality of extreme poverty. CHI put together regular exhibitions, and were located in an old colonial building the heart of the central gallery district in South Mumbai. Unlike other private galleries in the area, it was easy to enter CHI: there was no doorman or closed door with a camera as is usual practice. One could simply walk in through the open entryway, and I often found multiple artists and one of the curators sitting casually on the floor inside, socializing and sometimes eating or working. The space did not have white walls, as other galleries did; yet its exhibitions of visual and sculptural work were laid out in a familiar way, with labels underneath the works, as they would be in any gallery. During my interviews there, we sat either on the floor in the hall, barefoot, or in a back air-conditioned room. The group's myriad interests reflected in their ethos as a space that, like other alternative structures, is also process and action. A shifting group of "ten-plus people" at the time, membership was fluid but underwritten by democratic values that served artists:

We expect a person to have certain kind of values, no racists or classists. It's a utopia we want to have exist here. Like, 'Oh, why can't the servant serve me? Oh, the drivers and such shouldn't be in here ... and I've heard this kind of talk in the museum setting. We don't take any of that here.

This was Sumesh Sharma, one of the founders', description of membership requirements. CHI thus sought a certain type of artist or curator as member, defined by their inner qualities and values, rather than external socioeconomic status. To illustrate, he contrasted CHI members with the viewership of the India Art Fair, held annually in Delhi attended by galleries and catering to collectors. Whereas the latter was exclusively elite and commercial, $\mathrm{CHI}$ was open, democratic, and non-profit. They did sell works, but made sure artists got a segment of profits and they put their own profits back into running the space. Like other alternative structures, there was a clear critique of the gallery system's "mercantile circuits". CHI ran on bartering labor amongst members, and refused funding because of the "inflexibility" that came with it, obligations and strings attached. They took on commissions to help fund themselves.

Cona, by contrast, was several kilometers away, north of the city center, in the suburb of Borivali. Many artists live in the area. Like CHI, it was established in 2010, by an artist couple, Shreyas Karle and Hemali Bhuta. Cona was run solely by artists and focused primarily on helping artists. It fostered dialogue among artists as well as providing support through talks, residencies, resources, feedback, and social events, and did not display art. As illustrated in the vignette opening this article, Cona also has a pedagogical dimension, supporting art students intellectually and professionally. Karle described

2 See on international collaborations of Clark House Initiative: https://www.e-flux.com/announcements/31627/internationalcollaborations-with-clark-house-initiative/; other collaborations: https://www.theshowroom.org/exhibitions/workingpractices-a-collaboration-with-clark-house-initiative. 
it as a Sunday "adda" for students from different Mumbai art schools, as well as for older artists. ${ }^{3}$ Cona paid especial attention to students from more marginal backgrounds and schools in the city. This critical perspective is illustrated in Karle's support of a program put together by students from Vasai, an art college far north of Mumbai, written on Facebook in February 2014:

the only purpose this note serves is it caters to the humble approach made by the Vasai students. It maybe tries to address the issue of the marginalized, since the river of hierarchy that originates with J.J. School of Arts, based in the South of Mumbai, probably narrow's down to small streams in ... its course to reach Vasai [sic].

The passage refers to an effort by students, many of whom were Cona attendees, who put together a show of their works that never made it into the annual college display. Karle, speaking on behalf of Cona, voices support of artists coming from more marginal art colleges in Mumbai like Vasai, which he contrasts with the most well-known college at the top of the city's art hierarchy, JJ School of Art, which was established by the British in the mid-19th century.

Cona transformed during and after my period of fieldwork there, between 2013-2014, 2017, 2018, and 2019 and resisted institutionalization consciously, like other alternative art structures (Ault 2002). It evolved in response to trial and error and changing demands on its leaders and the needs of artists. The Sunday meetings eventually stopped, as I found out in 2018 on a return visit. The group took on two other codirectors and financial support and evolved its pedagogical and residency programs. This evolution is a natural aspect of such spaces, which are financially unstable because they are autonomous, eschewing some types of financial support, and dependent on various others which come and go. Financial precarity inflects the identity of such spaces. Cona's spirit closely resembles this description of the early alternative space in New York City, 98 Greene Street. Its founder, Holly Solomon, gave the space to artists who could do what they wanted with it, which is why she didn't name it: "it was quite spontaneous on purpose-no particular schedule-an atmosphere of immediacy. Galleries and museums must plan ahead. At 98 Greene the artists created what happened ... the quality and spirit of the place was in this spontaneity" (Terroni 2011). This time-based, ad hoc, "anti-institutional" quality defined many alternative art spaces, which shift their practices continuously (Ault 2002, pp. 2-3). Similarly, Shreyas called Cona a "situation," pointing to a state bound by time and space, constantly changing, rather than an institution or something fixed in content or form. Importantly, this is why I focus on these two spaces at particular moments in time and their activities then and there, and not as enduring institutions or in terms of continuity.

While different in their approaches, Cona and CHI are both alternative structures in the Mumbai art world, that are shaped by, and respond to their political and economic contexts. Artist-centered and established shortly after the art market boom, both have as a main aspect critique of art's commercialization in India, and the consequences of these for artistic labor. According to their founders, $\mathrm{CHI}$ 's activities focused more on creating and curating socially critical art, and fostering a collective of socially diverse Indian artists, whereas Cona was an artist-led space of dialogue, and resources for artists in their practice. Both critiqued the gallery system and sought ways to give artists more agency in and over their work and career trajectories, as I explore next. They espoused a democratic ethos and advocated for artists' accessibility to the Mumbai art world. High prices, gallery gatekeepers, and English-centrism, as well as inequalities based on caste, class, and regional origin kept many at the margins of the art world, and both spaces self-described as "utopian" arrangements. The inequality artists confronted in the artworld was complex. The uncertainty of artist careers intersected with the deep economic, political, and social inequalities that already marked Indian society. These were compounded and refracted through artworks and artistic practice. $\mathrm{CHI}$

3 Chakrabarty (2008) describes adda as "the practice of friends getting together for long, informal, and unrigorous conversations," and as predominantly male and middle-class in its modern forms in public life (181). While Chakrabarty posits adda as a quintessentially Bengali practice, Cona is located in a different region of India, and mostly Maharashtrian. 
and Cona wanted to open art in India up, to make it less exclusive and elite so a range of artists could participate, engage in critique, and on a very practical level, find ways to economically sustain themselves no matter what background they came from. In the next sections, I explore how these democratic and anti-elitist goals of the leadership of these two spaces played out through, and were complicated by, artists' collective forms of engagement with these spaces, what they did there and their motivations for participation. Although artists supported and benefitted from these spaces' mandate for democracy, mutual help, and access outside of market concerns, they simultaneously envisioned their participation as supporting and channeling into their careers and future success in the art market, rather than rejecting the latter. I explore these dynamics next.

\section{Alone We Can't Do It, But We'll Get There Together}

At Clark House Initiative (CHI), I met a group of seven young artists in their twenties for the first time in 2013, and then met them again in 2014, 2017, and some of them in 2018. The group members called themselves Shunya, or "void" in Hindi. This name distinguished the collective from CHI as a whole, which they were also part of, and which had brought them together in the first place. Following an extensive group interview at $\mathrm{CHI}$ in Colaba, I went to the northern suburb of Goregaon soon after to meet the group again in their shared home and studio space there. The group lived together; we sat on the floor in a circle to talk, and they took turns telling me their personal biographies, artistic ambitions, and how they came to live and work together. Afterwards, they took me on a tour of their individual rooms and showed me some of their artworks, and we then took a walk to a shared studio space they used nearby.

The artists all came from a wide variety of socioeconomic backgrounds, and most of them were from the state of Maharashtra, though not Mumbai. By living and working together, the artists could afford living in Mumbai, and they helped one another financially, practically, and collaborated artistically. The group was comprised of five young men and two young women. ${ }^{4}$ Whereas the curators leading $\mathrm{CHI}$ highlighted the collective's goals and reasons for existence more in ideological terms, as a critique of the elitism of the Indian artworld, strikingly, the artists explained their collective engagement rather in terms of how it facilitated their work and individual career aspirations. Their explanations were pragmatic, and they all emphasized how they came from non-art-related backgrounds. For example, Jay was in the final year of his masters program at the JJ School of Art. ${ }^{5}$ His father was in the Indian Air Force, and Jay had gone through the 12th standard in a military school. While all his friends, especially those from military families, were filling out forms to study engineering in college, Jay was interested in interior design. His high marks on the entrance exam to JJ School meant he did not get into interior design, but was accepted into painting. As a result, he said, "My dad kicked me out; he said I was wasting my future. Most Indians are very safe in their lives, they don't like taking risks". Jay continued his art studies, which he funded first by working 18-hour shifts in a call center in the city of Pune, then taking a train to Mumbai for class afterwards. In his second year, he worked at McDonald's, which he disliked because he "was so afraid of how people would react if I told them, like calling me, 'waiter.'”

Over time, Jay developed his confidence in his practice, and after the initial difficult years, and once he joined CHI, he began to see the possibility of a career in painting, even though it was less applied and technical than his original love for interior design. "I finally felt like I could do this, do painting". He liked painting because it meant working as an individual artist, and offered the possibility of

4 A note on their backgrounds. One of the two women came from a family of jewelers; the other was a police officer's daughter. Among the five men: one's father was a railway guard; another an Air Force family; a third came from a coal mining background, and a fourth was from a farming family.

5 A pseudonym. I use the actual names of the founders of CHI and Cona, because their voices in this article speak specifically to the aims, origins, and practices of their respective organizations, and to this extent, they are publicly visible and known. Beyond that, the names of participating artists are all pseudonyms. 
making a name for himself: "If I'd been making interior design, it'd be under someone else's name. It's an amazing feeling when someone comes to me and says, 'Jay, I really loved your work.'” All seven artists described how they dreamed of individual success in their careers, and how working and living collectively supported these goals. Jay explained:

Art will give you everything-fame, reputation, money, respect-all you have to do is stay and you'll get there. There's also luck. All of us [in the group] have this confidence, we don't switch around like other artists do, we stick with it, because we are there for each other. With personal difficulties, too, like family, relationships, we have each other. It's the best thing. [my italics]

Jay expresses his desire for personal career success (fame, money, reputation respect) as an artist while simultaneously contending that the strategies for achieving these were inherently collective for him ("we" have a confidence, are not like "other artists," are able to stick with it and have support other artists do not). While embracing an individualist, neoliberal logic of work success (Jay sees his success as down to his personal degree of effort) and classic model of the artist as solo creative author (he wants to make a name for himself), he also acknowledges and credits collective activities and support with enabling individual success. In the meantime, his parents had come around, witnessing their son's success, and every time they saw something in the newspaper about their son and CHI, they sent him the clipping.

A second artist in the group, Dilip, came from a less privileged background than Jay, and echoed similar sentiments. Dilip also credited belonging to $\mathrm{CHI}$ and a collective as giving him the ability to "stick with it," that is, to continue with the path of career artist even while those around him switched fields or quit. In Dilip's case, this was about the group boosting his sense of confidence. His father worked as a guard in the railways and he also studied painting at JJ School. His lifestyle as an artist was very different from his family's, and the group's support and lifestyle provided him, he said, with a sense of exceptionalism as an artist as well as confidence and security about his future.

Most students-99.9\% — shift fields to animation, illustration, Photoshop in the end-but most people start in art for the first, second year... we stayed, [because] we've had luck, finding these people at the right time, in the right place, the right people. Art isn't a one-man army. [my italics]

Dilip talks here about sticking with studying painting, and becoming a professional artist (a "serious" artist, in Plattner's terms, see Plattner 1996), rather than a worker in the creative industries more broadly, like an animator or illustrator. Artists often talk about the difficulty of working professionally in art, because it is so competitive, work is uncertain, and few artists are able to maintain a livelihood with their art. Belonging to a collective, and to CHI, enabled Dilip to continue with art where he might have given up otherwise because it was too difficult to succeed. While his co-artists provide him with moral support and they share collective living and material support, CHI brought them together (this is who he means by the "right people"), and provide training and exhibition opportunities and space in Mumbai, as well as support.

Vipin, a third member, credited the group with enabling him to enter "a rich person's" field. For his family, who were farmers, art meant craft-making, something he had engaged in since childhood. His grandparents made folk art, blankets, and pants. Later, Vipin thought that doing art was limited to drawing and painting: "where I'm from [these are] just a hobby, not a profession ... My family didn't want me to enter this field. They think it's just for rich people, enjoying art. There are lots of art schools, but they cost a lot of fees". Still, Vipin decided to pursue art and moved to Mumbai to study. He realized that contemporary art was a far larger field than drawing and painting. Joining CHI and being part of an artists' collective gave him the confidence to continue what to him was an unusual and unconventional career path: "Being an artist is not living like a common man. It's about the individual, doing your own thing. I'm not sure how long I can continue this, but I'll continue as far as I can go". Like the other members of the group, Vipin saw being an artist as an expression of himself as an individual, reflecting classic Euro-American notions of the artist. At the same time, success as an artist 
was to be realized through and by working with other, like-minded artists, and this was important for him, especially given that he came from a background where these views were unfamiliar.

Concretely, the group of seven artists shared and cut expenses by living together. They supported one another morally and emotionally, and gave feedback on one another's work and worked on their mutual projects. The barter of resources and labor was a basic practice at CHI, according to Sumesh Sharma, reflecting the initiative's ethos of accessibility:

We don't charge anyone when they come to Clark House, but there's a certain commitment. If we work on your exhibition, you work on everyone else's exhibition. We don't provide money but we provide expertise on exhibition, installation, all the things that cost to make an exhibition.

The artists extended this ethos to their daily living and work practices, picking up and weaving the network of collective support where CHI left off and overlapping with their work there. Shefali, another member, explained that the group also worked on commissions together, including recently a bust they made to celebrate the retirement of a well-known Mumbai-based industrialist. The fees they made from such commissions were shared among them, she said, and used to pay their living costs like rent and food. I walked with them from their apartment to a nearby space which was their studio, which they had also garnered access to from two senior artists who also lived in the same neighborhood and shared use of.

\section{Counterbalancing Gallery Power through the Alternative Space}

One institution loomed largest in the imaginaries and everyday talk of artists when reflecting on their work and careers, the commercial gallery. The elite center of the Mumbai art world is dominated by galleries, mostly located in South Mumbai. These galleries are privately owned, usually run by one (or two) dealer, and are "white cubes" - they look very much like commercial galleries all over the world. Galleries are material expression of the art market, and a key site of art's symbolic and economic exchange (Debroux 2017). Most galleries in Mumbai were established from the late 1990s onwards, and primarily in the 2000s, during the art market "boom". While over the years the composition of these galleries has changed here and there, as some close and others open, the ideal for many artists is to (ultimately) be represented by a private gallery in Mumbai and/or Delhi. There is a power imbalance between galleries/dealers and artists that tips far in the favor of the former. This is for different reasons. First, there are far more artworks than there are buyers for them, and it's a vast and undifferentiated market in which artists struggle to stand out (Menger 2001). These findings in relation to Europe and America probably hold even more true in India, where dealers and artists alike commonly lament and comment upon the paucity of collectors. ${ }^{6}$ Secondly, many more artists aspiring to "avant-garde status" exist than dealers to represent them (Plattner 1996, p. 198). This gives dealers power of representation of an artist, whose main rule is exclusivity, meaning a dealer can monopolize sales of an artist's work in a particular area. Dealers claim in turn that they legitimize the value of an artist's work in the market, that the artist's affiliation with the gallery is what gives the artist status in the market and enables sales, whether or not the specific work has passed through the gallery (ibid.). In Mumbai, dealers also provided visibility and helped to produce legitimacy for artists, by giving them regular shows at their galleries, featuring their names and works on their websites and social media, sometimes facilitating press coverage, and finding buyers for their works, as dealers have access to collector and institutional networks.

Artists I spoke with in Mumbai always told me that they aspired to representation, usually of a South Mumbai gallery, while also expressing ambivalence about gallery power over artists. They regarded galleries as institutions that, while necessary to their careers, were too powerful and 
financially motivated, as well as elitist. According to those who took part in them, $\mathrm{CHI}$ and Cona were ways of counterbalancing the power of galleries in relation to artists. This independence was twofold. Firstly, it was about artists depending less on galleries to be able to work and be recognized as a "real" artist. This meant finding ways to make money from one's work outside of gallery sales, as well as achieving validation in the art world via shows and opportunities to display one's work, sometimes outside of the gallery circuit (c.f., Bourdieu 1985). Secondly, the independence meant freeing oneself from the constraints of one's background, such as language or class limitations, to be able to freely access galleries for possible representation.

Artists at the alternative spaces positioned the galleries as necessary evils, as simultaneously desirable affiliations yet often out of reach and frequently undemocratic in their practices, both in their selection of artists to represent and in how they worked with the artists in their stables. Artists did not reject the gallery outright; rather, they recognized galleries' power and sought collective ways to etch out limited independence from them through alternative spaces and to improve their chances of succeeding in the gallery system, thus reinforcing the hegemony of the latter. This positioning is somewhat different from that of artists in the early alternative spaces in New York City, where the commercial system of art display and circulation was entirely rejected and alternative spaces positioned themselves as an outside and actual alternative to the mainstream gallery. The artists I met at Cona and $\mathrm{CHI}$, were rather looking for ways to work within the gallery system, but on their own terms, and to soften what they saw as the dominance of galleries on artist careers. Jay, from CHI, expressed the power of the gallery in this way: "We [artists] know that no matter what we'll be part of the white cube system;" and Vipin said, "We have to deal with them [galleries]". Similarly, Shreyas, from Cona, said, referring to galleries, "If you're not in that system, you almost don't exist ... There are lots of names [of artists] that don't exist because they're off the mainstream". Gallery representation conferred status and validation of artistic identity onto artists, just as not having representation could feel like negation of that identity. Cona was a way for an artist to exist and have visibility without the gallery. It was a "parallel system" to the galleries, not an opposition to them,

We don't want to be like that [galleries]. But we have to exist. These situations [Cona] don't exist here, not in Bombay ... It's a different platform for people to locate themselves in. Think of Google Maps. If you're not on the map, it's like you don't exist, but it doesn't mean you are not there... You don't need an authority to underline your existence.

Of course, the point Shreyas makes here is that artists did feel the need for an authority - the gallery or museum's view, analogized as Google Maps, to recognize their existence to be "real" artists, but he felt it should not be this way. Cona, while eschewing the label of institution, was a platform for artists to locate themselves in the city's (and country's) art landscape without a gallery. Artists thus wanted to counterbalance the power of galleries by finding ways to carve out independence from them in their careers. This entailed finding ways to generate income and sustain livelihoods outside of the gallery; achieving artistic validation beyond the commercial gallery; and support artists in finding their way into the gallery system they simultaneously critiqued and accepted. Cona and CHI enabled artists to address these issues collectively, and find potential solutions. Prabhu from CHI described the freedom artists wanted in terms of financial independence:

Money fucks art up. Money is the most important thing ... Galleries are so concerned with the selling part. We are advised by senior artists to show you have enough money, otherwise they'll pressure you to make works in the way they want. It'll reverse if they think you're stable.

Having enough money for Prabhu meant an artist demonstrating that she or he was economically solvent, and with income. The greater an artist's economic independence from a gallery, which meant not needing the gallery to sell one's work, the greater their possibilities to make works as they wished within that system. He gave the example of artist Riyas Komu's series of works on oil politics, 
a potentially politically charged topic, as shown in works like Designated March of a Petro-Angel (or Desert March), 2006. ${ }^{7}$ Komu, an extensively validated artist, was, according to Prabhu, asked to do a part two of these works by his gallery, because he is economically viable, or at least believed to be. Jay added, "The gallery depends on the artist, but the gallery has power that artists should have. The gallery is like designers [sic], shaping what Indian art is being made". Financial freedom was equated with artistic and creative freedom, because it freed the artist from dealers telling them how to work, what kind of art to make, and how much to produce, while still enabling the artist to participate in the gallery system to have representation and make sales.

The two independent spaces experimented with different ways of addressing the issue of income and livelihoods as well as how to validate one's work as an artist in the absence of current gallery representation. CHI held regular shows in their South Mumbai space, where the Shunya artists showed their work in the heart of the city's art district. Their location meant that they were part of the gallery circuit and events like Art Night Thursday, when all galleries were open until 9 p.m. once a month for gallery walks. CHI also collaborates with art initiatives in Europe, the UK, and elsewhere, which provides their artists with a means of showing their work on a broader stage, thus achieving some institutional validation. CHI was able to achieve these through their practices of sharing labor and materials among artists; and because the curators provided expertise and networks to support their artists. Both Sumesh and Zasha were English-fluent and highly-educated, and had worked extensively in the Indian art world before starting CHI. Sumesh explained: "We work on commitment-there's no money but there is expertise about all the things that cost for an exhibition. [It's] a barter system. That's how we're able to support everyone and remain who we are".

Members worked collaboratively, mutually donating time and labor to put together shows, which in turn created a more democratic art exhibiting system than a gallery. "We found it easier to survive if we were paying each other. Everyone gets a turn, but with no formality" (Zasha). "Doing" art is a collective process involving a high division of labor. In these Mumbai alternative spaces, artists, rather than solely occupying a privileged position as gifted author within the art making process, performed work usually tasked to other art world actors for one another in order to save labor costs, enable accessibility, create opportunities to show their artworks, and generate income. Rupa, an artist at CHI, said, "Each of us has a slightly different skill set". They also had access to different resources, which artists and curators exploited to put together and curate exhibitions without the intervention of a commercial gallery or dealer. The artists were very positive and appreciative of the knowledge and support they got; three artists recounted how much they learned about art, politics, and history from the two curators. On a very practical level, artists could for example sleep or live at Clark House so that they could stay in the city and work, eschewing extremely expensive rent costs and avoiding having to travel back to homes far out in the city's suburbs at night. In addition to artists' co-living and coworking practices as described in the previous section, at CHI itself they also sold work from their shows, and worked on commissions to support themselves. Both the curators and the artists rejected the idea that art should not be for profit, finding this an elitist idea that was condescending to artists who did not have means, such as most of those at CHI (interview, 23 January 2014).

At Cona, artists sought to cultivate a degree of independence from, and in parallel to, the gallery system in different ways. One was through its pedagogical approach that supported young artists by providing them with feedback on their portfolios, as described at the start of this article, as well as skilling artists in modes of professional self-presentation that would help them approach galleries for representation, or apply for residencies. Cona held workshops, for instance, on how to write a residency application, and another on funding agencies, with the head of Gasworks as a guest speaker. When I met young art students there one Sunday afternoon, we discussed their interests, and how they were developing their topics for research in their art practice.

7 Komu's work is known for its treatment of issues around nation, citizenship, and history in India (c.f., Venkiteswaran 2019). 
A major advantage of working with a gallery is visibility, recognition of one's name, as linked to the gallery (Velthuis 2005). The gallery produces shows of an artist, and a range of texts to present the artist and accompany his/her work, summarizing and analyzing it in a short, packaged fashion. These artists wanted that, but were not part of any gallery stable. Taylor's work on female romance writers in North America is helpful for understanding what artists did at Cona. Writers create pen names and other "assets" for their imagined audiences, which are then animated by the authors, as well as publishers and others involved in book production to create value. "Creation and animation [were] imagined to create value for writers and publishers in an uncertain recession-era economy" (Taylor 2018, p. 113). The analogous "asset" for these artists at Cona was the notion of having a trademark "issue" in their words, a research topic of timely political or social relevance that they explored through their art practice. Young artists attended talks with visiting speakers, curators, and artists at Cona in the hope of finding their own "issue," that would characterize their work and be central to their portfolio. Then they developed ways of talking about their trademark issue with the help of Shreyas, Hemali, and other more senior artists there. Such assets enable a creator to create distance between parts of the self, such that an asset can be used for the industry, and exploited by others, like publishers (116), or here, by dealers/galleries. At Cona, young artists received help in cultivating such assets that, while often emerging from personal backgrounds and interests, were gradually distanced from themselves and spoken about as professional projects. Hemali described this distancing process, where a personal interest was developed into a clear project that could be presented in the right (English, art critical) language, as "articulation". It's "how to talk about something. You keep analyzing it to yourself, again and again". Then, an artist also had to "gather the guts" to communicate these to a gallery, to viewers, in a funding application. Young artists felt more confident about their professional futures due to the support they received and gave at Cona. One artist there, Mithu, said that having developed clarity about his issue, which was about childhood, he imagined that after working commercially for a year or two, he would be able to "make enough money and just do art," and achieve gallery representation.

There is a less directly economic way in which the independent art space cultivated artist autonomy from the gallery system, through identity work. As Plattner (1996) has argued, artists are "identity producers," "high-level" artists make art because of their self-definition as artists, not because of profit possibilities. Indeed, being an artist has to do with essential self-definition, which is why artists often keep producing art, even "though their art incomes do not match their opportunity costs;" that is, they could make more money doing other kinds of work (20). CHI and Cona also played a role in helping artists produce and sustain their identities as artists. This was not by making art directly per se as Plattner argues, but as venues of artist socialization and as art organizations that provided an anchor for artists' professional identities. Alternative art structures thus provide a "place to exist," like a marked site on Google Maps that is necessary, as Shreyas Karle described, for artists who otherwise had no gallery representation or market or institutional presence in the art world. In these spaces, artists met one another, socialized over drinks and food, and engaged in regular conversations about their work. For example, at Cona, artists sat around one evening and talked about how to balance artistic practice with other kinds of work, and whether or not making income from other work threatened the authenticity of one's artist professional identity. These spaces were thus sites of identity work, where artists co-produced themselves as artists, in the absence of other forms of art world validation such as museums or galleries. In this way, they did create more accessibility in the art world, by making it possible for a wider range of artists to inhabit and validate their artist identity, a fundamental aspect of self-definition. This also shows how artists, far from being isolated and self-focused solo beings, only interested in their individual success and creativity, prioritized social bonds and collectively worked to support one another (Brouillette 2014). 


\section{Alternative Space as Process: Evolution and Change}

A few years later, in 2017, I returned to Cona, which had changed location. Mithu was not yet where he wanted to be. He was working part-time doing work for an ad agency, and illustrating children's books, and spent time still at Cona. Another, Rupali, had tried to get into a masters program at the University of Baroda, but not managed to. "Most of them stopped coming," said Shreyas of the students, "as they slowly began to realize that we were not going to be launching their careers. Many of those students came here because they wanted to be validated. They didn't get that at school so they came to us so we would be like okay, and validate them. I think they saw Cona as a kind of entry point to then get into the art scene in South Mumbai, to establish their careers as an artist. Because the gallery system is the only way to make it as an artist here". Furthermore, most of the students who frequented Cona came from "lower-class backgrounds". They had a lot of pressure on them, no doubt, said Hemali and Shreyas, from their families to start making money soon after graduating. Shreyas told me about Yogesh, who I remembered from before. He had graduated from Vasai, where he is from. $\mathrm{He}$ is Koli, an indigenous fishing community. He used to be deeply involved with Cona, but gradually started coming less and less last year, until he stopped completely. Initially, he rented his own studio space with some of his friends "up in North," said Shreyas. "I thought, that's great, it's okay if he's not here, because being here has inspired him to go do something!" But this did not work out as well as Yogesh had hoped, and it was more difficult to maintain than he had thought. The cost was one issue, Hemali suggested. I wondered if it was also difficult to keep up a pace of regular work without the mentorship and social anchoring Cona had provided. Yogesh gave the studio up, then went and bought some second-hand busses, and started renting them out to people. He now runs a successful business doing this, Shreyas said. "Once in a blue moon, he calls up and says he misses being here, and that he wants to be making art again, and that he will come by sometime. But he never does". They seemed amused but also sad and tolerant of Yogesh's departure from fine art and his halfhearted hanging on via these occasional phone calls.

I think he saw a couple of his friends from school [Vasai] do really well after graduation, and they are doing shows, and even showing internationally, and this didn't happen for him, and he was really disappointed by this. I think these students are like, it's happening for them, why not for me? It's very difficult to persuade them that there is another way for you to do your art, to be an artist, than this system, and that you also can't expect things to happen overnight. You have to be patient. ${ }^{8}$ (Shreyas, also expressed by Hemali later)

"This is what I mean," he added. "They saw us as a validating institution, and this had to change. In some ways I feel like I have failed, that I could not convince him otherwise [to continue art]," he said. "He can find a way to keep doing the kind of art he was doing in his community, in an activist kind of way, without galleries, you know!" added Hemali. "But I don't know if he will".

However, these speak not of the space's failure, but rather to how alternative art spaces as time and context-bound situations that evolve through experimentation and respond to the needs of current circumstances. From this perspective, Cona imagined new ways to provide artists agency in their careers, and counterbalance gallery power. Shreyas told me that the space had been becoming an "institution," even a "validating institution" for the young art students, and he and Hemali did not want this. Cona had expanded rapidly, and was getting visibility on the international scene as well, and this meant that there were more expectations, and particular expectations of them. There were,

8 To extend (Plattner 1996), one might interpret the young artists leaving the field as a filtering mechanism, where the more serious artists continue to make art, while others move on to other work as art incomes fail to materialize and opportunity costs become too high for an artist. However, in the case of less-privileged artists who had to support their families or themselves, without family resources to fall back on, the turn to non-artistic work that generated income clearly also had to do with inequality in the art world. Making art requires space, materials, and time that are unequally distributed and accessible to artists. Once Yogesh left Cona, and graduated, his access to these reduced. 
too, "lots of people who were coming but were not giving anything; they were not contributing to the language, which is what Hemali and I wanted in the first place. People were just showing up, listening to a talk but not changing the language [of art]". (Shreyas) Further, the intense pace of activity-finding speakers on a weekly basis, doing student reviews, organizing things, opening their home to so many all the time - these events happened on Sundays - was exhausting. While they had self-funded their activities for a long time, they also decided to accept some financial support and take on new partners. "We stopped doing Facebook, we stopped doing the blog, we stopped everything!" It was a time to turn inward and reassess and reinvent.

Their pedagogical approach changed into a mentorship program, and Cona started a "design cell" called Kad Cona (meaning "right angle" in Hindi), whose inception was inspired to create a "parallel economic system" to the gallery system, which Shreyas still described as the only game in town for making it as an artist in India. Bridging fine art and design, they wanted to make products that could be sold in various commercial venues to generate income beyond the gallery. At the time, Cona was also participating in a show at the Whitworth Museum in Manchester to explore how to make this parallel economic system a reality. ${ }^{9}$ The founders were ambivalent about the potential to really live free of the gallery as an artist in India.

What we know is that is that we are not insecure anymore. Unlike our peers. I know that other artists of our generation are. They are always like, I am doing this, I am not doing that, what about this, what am I going to do, I don't have a show coming up, that kind of thing, you know? We don't have this.

The Cona founders had found validation through the gallery system themselves, which enabled them means to contribute to those who had not (yet). Yet their own career trajectories that were embedded partially in the gallery system pointed to the limits of what the alternative space seemed able to provide. By working collectively via the alternative space, they were able to temporarily "exit" the market and redistribute their own advantages to some degree among other artists less privileged in the Mumbai and India art economies, much in the way the curators at CHI did, to support less privileged artists in their practice. Simultaneously, Cona's evolution in this period, the perspectives of artists throughout this article, and the realities of the Mumbai art world suggest that the gallery's dominance as a key validating institution in an artist's career remained. Thus artists turned to alternative structures as means of entering the gallery-centered, South Mumbai art scene, and find gallery representation. This was even as for the founders of these spaces, the latter were a way to try and partially exit that scene. What Shreyas's and Hemali's story of what happened over five years at Cona (2013-2018) shows is how artists continue to respond collectively to address inequality and hierarchies in the Mumbai art world. Temporally and spatially bound "utopian" moments enable artists to transcend these inequalities, such as when young artists from lower socioeconomic backgrounds are able to develop means of articulating their research practice in contemporary art vocabularies, and imagine their career trajectories through the elite South Mumbai gallery, and successful, validated artists or curators are able to help and contribute to other, less privileged artists, and to incorporate these activities into their own artistic practice and professional identity.

\section{Conclusions}

Alternative spaces are a means for Mumbai-based artists to respond to and cope with market effects on artistic labor and careers. These take collective form, challenging dominant characterizations of the artist and creative producer as staunchly individualist and competitive, of artistic labor as happening

9 For their exhibit they focused on the Weavers Service Centre, established in the 1950s. Many artists who found success, nationally and even internationally, such as Prabhakhar Barwe, worked at the WSC for many years to support themselves while they worked as artists alongside, designing textiles. The exhibit: http://www.conafoundation.net/curatorial-projectdetails.php?id=26. 
in solely isolated, autonomous, self-oriented ways, where artists smoothly embrace uncertainty and insecurity as flexibility and freedom. I contend that we take seriously how these notions of artistic identity and work organize and inform the work and lives of artists and reify certain power relations, shaping how an artist feels they can or cannot act in the world, achieve success or not, and achieve artistic validation in the relative absence of opportunities and resources. This article extended a discussion of collective practice in contemporary art to how it is enacted in artists' lives as workers, who are not only commentators on economic, political, and social change, but subject to it as artistic laborers working in specific, historically-located contexts. What I hope to have shown via the example of Mumbai is that alternative art spaces play a significant role in: (1) providing unknown artists the opportunity to learn skills necessary for their work, whether artistic in the shape of feedback or ideas, or professional in the form of networking or how to speak the language of art criticism; (2) professional identity production and maintenance for artists as social spaces and as sites providing artists belonging and visibility, albeit to a limited degree, in the art world; (3) providing practical sources of emotional, moral, and even material support in a competitive art market; and (4) enabling unknown, young artists to enter, and more senior, validated artists to partially exit the art market. These key features of alternative art spaces and art collectives more generally may be especially marked in contexts across the Global South, where art infrastructures, like galleries, museums, residencies, funding programs, and public support, may be significantly limited and emerging, as is the case in India. These spaces offer a set of alternatives to the art market as embodied by the gallery system: through them, artists work to counterbalance gallery power in their careers, artists from less-privileged backgrounds seek inclusion, and they reward artists with artistic validation, albeit in a more limited fashion than art market institutions like galleries or art fairs.

They are not, like early versions, attempts to exit the market or find an exterior to capital, but temporary, in-flux, dynamic, collective processes that come and go that are means of coping with, accommodating and resisting the market's effects via artistic labor. These spaces are thus interrelated with the art market via the artist him/herself, and should be considered within the same analytical frame.

Funding: This research was funded by the Amsterdam Centre for Globalisation Studies (2011-2013) and the Amsterdam Institute for Social Science Research (2014-2018).

Conflicts of Interest: The author declares no conflict of interest.

\section{References}

Ault, Julie. 2002. Alternative Art New York 1965-1985: A Cultural Politics Book for the Social Text Collective. Minneapolis: University of Minesota Press.

Becker, Howard. 1982. Art Worlds. Berkeley: University of California Press.

Boltanski, Luc, and Eve Chiapello. 2005. The New Spirit of Capitalism. Translated by Gregory Elliott. London: Verso.

Bourdieu, Pierre. 1985. The Market of Symbolic Goods. Poetics 14: 13-44. [CrossRef]

Bourdieu, Pierre. 1993. The Field of Cultural Production: Essays on Art and Literature. Cambridge: Polity Press.

Brouillette, Sarah. 2014. Literature and the Creative Economy. Stanford: Stanford University Press.

Chakrabarty, Dipesh. 2008. Provincializing Europe: Postcolonial Thought and Historical Difference. Princeton: Princeton University Press.

Chibnik, Michael, Rudi Colloredo-Mansfeld, Molly Lee, B. Lynne Milgram, Victoria Rovine, and Jim Weil. 2004. Artists and Aesthetics: Case Studies of Creativity in the Ethnic Arts Market. Anthropology of Work Review. 25: 3-8. [CrossRef]

Debroux, Tatiana. 2017. The visible part: Of art galleries, artistic activity and urban dynamics. Articulo. Journal of Urban Research 15. [CrossRef]

Enwezor, Okwui. 2005. The Artist as Producer in Times of Crisis. Available online: https://engagement2017.files. wordpress.com/2017/03/enwezor-the-artist-as-producer-in-times-of-crisis.pdf (accessed on 10 October 2020). 
Florida, Richard. 2002. The Rise of the Creative Class: And How It's Transforming Work, Leisure, Community and Everyday Life. New York: Basic Books.

Gerber, Alison. 2017. The Work of Art: Value in Creative Careers. Stanford: Stanford University Press.

Gerber, Alison, and Clayton Childress. 2017. I Don't Make Objects, I Make Projects: Selling Things and Selling Selves in Contemporary Artmaking. Cultural Sociology. 11: 234-54. [CrossRef]

Kelley, Bill, Jr., and Kester Grant, eds. 2017. Collective Situations: Readings in Contemporary Latin American Art, 1995-2010. Durham: Duke University Press.

Kester, Grant. 2011. The One and the Many: Contemporary Collaborative Art in a Global Context. Durham: Duke University Press.

Komarova, N. 2017. Ups and downs of art commerce: Narratives of 'crisis' in the contemporary art markets of Russia and India. Theory and Society 46: 319-52. [CrossRef]

Mazzarella, William. 2003. Shoveling smoke: Advertising and globalization in contemporary India. Durham: Duke University Press.

Menger, Pierre-Michel. 1999. Artistic labor markets and careers. Annual Review of Sociology 25: 541-74. [CrossRef]

Menger, Pierre-Michel. 2001. Artists as Workers: Theoretical and Methodological Challenges. Poetics 28: 241-54. [CrossRef]

Myers, Fred. 2002. Painting Culture: The Making of an Aboriginal High Art. Durham: Duke University Press.

Papastergiadis, Niko. 2011. Collaboration in Art and Society: A Global Pursuit of Democratic Dialogue. In Globalization and Contemporary Art. Edited by Jonathan Harris. Malden: Wiley-Blackwell, pp. 648-83.

Plattner, Stuart. 1996. High Art Down Home: An Economic Ethnography of a Local Art Market. Chicago: University of Chicago Press.

Rachleff, Melissa. 2012. Do it Yourself: A History of Alternatives. In Alternative Histories. Edited by Rosatti Lauren and Mary Anne Staniszewski. Cambridge: MIT, pp. 23-40.

Sharma, Ravi Teja. 2012. Artist Subodh Gupta buys Delhi house for Rs 100 crore. Economic Times. July 16. Available online: https:/economictimes.indiatimes.com/wealth/personal-finance-news/artist-subodh-guptabuys-delhi-house-for-rs-100-cror/articleshow/14968465.cms (accessed on 29 November 2018).

Singh, Kavita. 2010. A History of Now. ARTIndia 15: 26-33.

Sooudi, Olga Kanzaki. 2018. Market memories: Collective memory and art market change in Mumbai. Poetics 71: 83-94. [CrossRef]

Taylor, Jessica. 2018. Animating creative selves: Pen names as property in the careers of Canadian and American romance writers. American Ethnologist. 45: 112-23. [CrossRef]

Terroni, Cristelle. 2011. The Rise and Fall of Alternative Spaces. Books E Ideas. October 7. Available online: https://booksandideas.net/The-Rise-and-Fall-of-Alternative.html (accessed on 10 August 2020).

Vasudev, Shefalee. 2012. Powder Room: The Untold Story of Indian Fashion. Noida: Random House India.

Velthuis, Olav. 2005. Talking Prices: Symbolic Meanings of Prices on the Market for Contemporary Art. Princeton: Princeton University Press.

Velthuis, O., and S. Baia Curioni. 2015. Cosmopolitan Canvases: The Globalization of Markets for Contemporary Art. Oxford: Oxford University Press.

Venkiteswaran, C. S. 2019. Frontline. Sculptor Riyas Komu: An argument about Beautiful Histories at Risk. The Hindu. September 27. Available online: https://frontline.thehindu.com/arts-and-culture/art/ article29381850.ece (accessed on 10 August 2020).

Win, Thet Shein. 2014. Marketing the Entrepreneurial Artist in the Innovation Age: Aesthetic Labor, Artistic Subjectivity, and the Creative Industries. Anthropology of Work Review 35: 2-14. [CrossRef]

Yee, Amy. 2012. An Edgy Art Haven in India Gains Momentum. The New York Times. January 20. Available online: https://www.nytimes.com/2012/01/21/arts/21iht-scdelhi21.html (accessed on 10 August 2020).

Zarobell, John. 2017. Art and the Global Economy. Oakland: University of California Press.

Publisher's Note: MDPI stays neutral with regard to jurisdictional claims in published maps and institutional affiliations.

(C) 2020 by the author. Licensee MDPI, Basel, Switzerland. This article is an open access article distributed under the terms and conditions of the Creative Commons Attribution (CC BY) license (http://creativecommons.org/licenses/by/4.0/). 